\title{
THE YEAR OF THE SCAPEGOAT:
CHINESE IN BRITISH COLUMBIA Nick Stember
}

$\boldsymbol{B}_{\text {to an immigrant investor pro- }}^{\text {ETWEEN } 2005 \text { AND 2012, thanks }}$ gram, 36,892 millionaires emmigrated to British Columbia (BC). With sixty-six percent hailing from mainland China, and another fifteen percent from Hong Kong and Taiwan, greater Vancouver's ethnic Chinese population grew from 17.5 percent of the population in 2001 to 18.7 percent of the population in 2011. ${ }^{17}$ This demographic shift coincided with the city's benchmark house price in 2016 rising to CA $\$ 1.4$ million - double what it was in 2005 and out of range for many other citizens in a city where the median family income is CA $\$ 76,040 .{ }^{18}$ While housing prices were doubling, inflation-adjusted income growth in $\mathrm{BC}$ was far and away the worst in Canada - falling by as much as 2.4 percent according to some estimates. ${ }^{19}$ This strange state of affairs led some analysts to argue that an influx of wealthy Chinese immigrants generating most of their wealth overseas had allowed the housing and labour markets to decouple - a troubling conclusion in a city with a long history of anti-Chinese racism.

Many Chinese immigrants like to joke that Vancouver, and BC in general, is 'so pretty, so clean, so boring' 好 山好水好无聊. In the media, the mainland Chinese community in particular has become famous for ostentatious displays of wealth, with teenagers at the wheel of Lamborghinis, college students buying mega-mansions, and other jaw-dropping displays of conspicuous consumption such as those that feature in the web series Ultra Rich Asian Girls of Vancouver. The ar- 


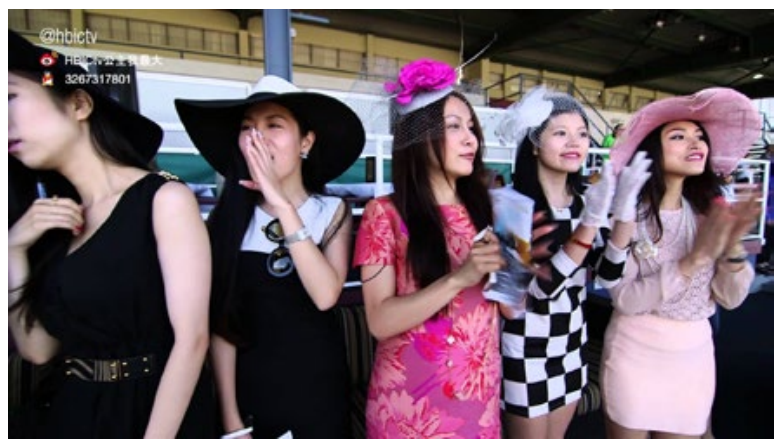

Still from Ultra Rich Asian Girls of Vancouver Source: YouTube

rival of wealthy mainland Chinese has provided a stark example of the effect of rising income inequality on house prices within Canada, exacerbating a problem that predates the investor immigrant program by decades. It has also obscured the arrival of non-investor Chinese immigrants providing much-needed skills and labour in a country with declining fertility. Tensions are simmering, and many liberal Vancouverites who pride themselves in BC's more recent ethos of multicultural inclusivity find themselves struggling to understand their own city's dark and racist past.

\section{Making Tracks}

As with the Irish potato famine and related demographic crises in rural Sweden and Italy that sparked waves of immigration across the Atlantic, the
Taiping Rebellion (1850-1864) and resulting Punti-Hakka Clan Wars 土客械 斗 in Guangdong province sent struggling farmers and merchants in southern China to Canada in search of new opportunities. The first wave came in 1858, during the Fraser Canyon Gold Rush. The second arrived when BC demanded a railroad link to the east as a condition of joining the Canadian federation in 1871.

BC's first census, carried out that same year, recorded some 3,000 Chinese residents - ten percent of the total population of BC at the time, and over ninety-nine percent of Chinese immigrants in Canada. Despite widespread racism against the Chinese immigrants, with 'Chinamen' (along with 'Indians') being stripped of the right to vote in $\mathrm{BC}$ provincial elections in 1872, over the next four years some 
15,000 Chinese were brought into the province to work on the railroad. They were paid CA $\$ 1$ a day - one-third of the wage of other workers. They were also consigned to the most difficult and dangerous passages: an unrecorded number of Chinese labourers were injured and killed during the difficult (and rushed) tunnelling and bridging of the Rocky Mountains; another unknown but far larger number deserted the railway for the gold mines. A new wave of immigration began when gold was discovered in the Klondike in 1886.

\section{Exclusion and Inclusion}

Once the railway was finished, the federal government quickly established a head tax to discourage further Chinese immigration. The tax, originally set at CA $\$ 50$ but eventually reaching CA $\$ 500$, and other exclusionary, racist practices, including expanding the disenfranchisement of Chinese British Columbians to federal elections in 1899, meant that while the overall population of BC increased eight-fold between 1891 and 1911, the Chinese population was kept at an artificially low 14,000 residents. Even this small number was a point of contention for the Trades and Labour Council-sponsored Asiatic Exclusion League, which

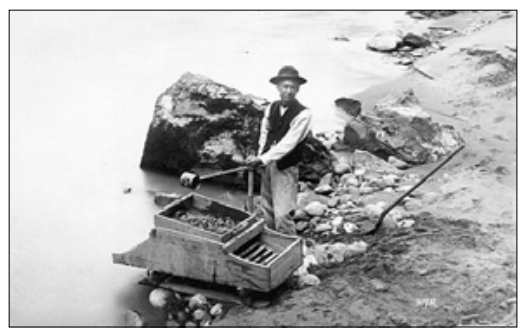

A Chinese man washing gold in British Columbia's Fraser River around $\mathbf{1 8 7 5}$

Source: collectionscanada.gc.ca

staged a riot in Chinatown in 1907, blaming the Chinese for accepting lower wages and stealing jobs from white British Columbians.

Ten years later, World War I saw some 80,000 Chinese labourers travel to Europe to aid the Allied war effort by digging trenches. They travelled via Canada in cattle cars on the same railroad their compatriots had built just three decades earlier. Meanwhile, many Chinese Canadians joined the service to fight alongside their fellow countrymen. Yet in 1923, the Canadian government promulgated the Chinese Immigration Act, outlawing ethnic Chinese immigration with but a few exceptional cases. The Act was not repealed until 1947 - a condition of Canada's signing the UN Charter on Human Rights. Two years later, Chinese British Columbians were allowed to vote again for the first time, since their provincial and federal voting rights had been suc- 


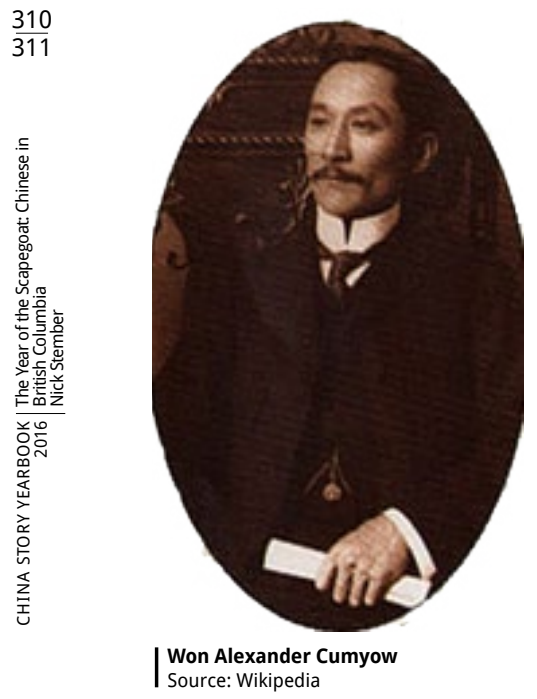

cessively taken away in 1872 and 1899, with Won Alexander Cumyow 溫金有 (1861-1955) becoming the only Chinese Canadian to have voted both before and after the exclusion acts, having last cast his vote in the 1890 federal election.

Only in the late 1960s did Canada overhaul its immigration policy, allowing qualified immigrants to settle in Canada irrespective of their country of origin. Following the Sino-British Joint Declaration of 1984, in which Britain pledged to return Hong Kong to Chinese sovereignty in 1997, and the bloody crackdown on the student protests in Tiananmen Square on 4 June 1989, wealthy Hong Kong Chinese became one of BC's largest immigrant communities, with some 241,000 HongKong Chinese living in Canada by 1996, many of them in Vancouver. The more recent wave of Chinese immigrants from mainland China has boosted the overall Chinese population of Canada to nearly 1.5 million, or 4.5 percent of the total population. While Ontario has greater absolute numbers of ethnic Chinese in its population than $\mathrm{BC}$ (about 750,000), they only make up five percent of the population of the province, whereas the 500,000 ethnic Chinese British Columbians make up more than ten percent of the total population of the province - roughly the same ratio as when the first census was conducted there in 1871.

Twenty-first-century Chinese immigration to Vancouver has revived old concerns about racial mixing and changing cultural norms. Like the Asiatic Exclusion League before them, fringe groups such as the Council of European Canadians and Immigration Watch Canada have used the concurrent phenomena of rising house prices and stagnating incomes to argue that immigration from non-European countries, and from China in particular, represents a threat to Canada's social cohesion and economic wellbeing. 
In February 2016, the ruling Liberal Party of BC commissioned its own study of foreign ownership of provincial real estate. Before the study was completed, however, BC Premier Christy Clark instituted a fifteen percent foreign transfer tax in August. Although the tax aims to curtail real estate speculation by wealthy overseas investors whatever their country of origin, to some it calls to mind the institution of the head tax of 1885 .

Interestingly, in 2016, it is some members of BC's ethnic Chinese population who have led the debate, defusing some of its racial elements. Among them is Eveline Xia, who is behind the lively Twitter hashtag \#donthave1million; urban planner Andy Yan, who conducted a controversial study drawing an explicit link between new Chinese wealth and the overheated housing market; and Ian Young, a former editor with the South China Morning Post whose 'Hongcouver' blog ran a story on 24 November with the headline: 'Vancouver's mayor never dreamed foreign-funded housing crisis would get so bad. If only he'd been warned ...'

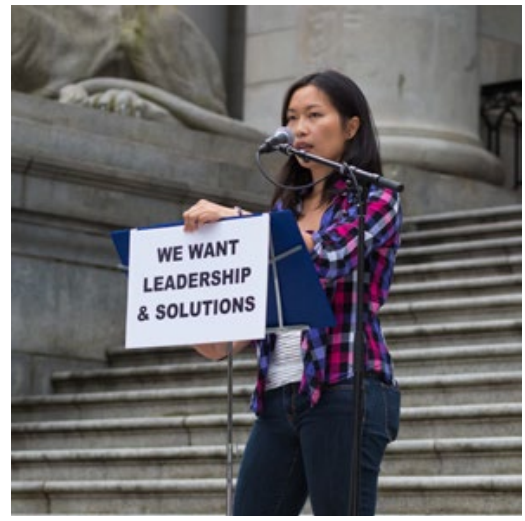

Eveline Xia

Source: Mark Klotz, Flickr 
This text is taken from China Story Yearbook 2016: Control, edited by Jane Golley, Linda Jaivin and Luigi Tomba, published 2017 by ANU Press, The Australian National University, Canberra, Australia. 